\title{
法律文献の検索とレファレンス事例：早稲田大学中央図書館レファレンスカウ ンターにおける事例を中心に
}

\author{
服 部 光 泰* \\ 早稲田大学中央図書館総合閲覧課
}

\begin{abstract}
Hattori M. (Waseda University Library Department of Accession Services. 1-6-1, Nishi-waseda, Shinjukuku, Tokyo 169-8050, Japan): Legal research and Waseda University Central Library's reference cases. Igaku Toshokan 2003; 50(1):41-45.

This article explains how to search current Japanese law, extraordinary law, ordinances, and court precedents mainly by using on-line databases. It also describes reference cases concerned with legal research at Waseda University Central Library.

Key words: legal research
\end{abstract}

\section{I 、はじめに}

早稲田大学中央図書館レファレンスカゥンターには, 試験期の多い日になると 1 日で 200 名を超える利用者が 訪れることあある。そのなかで法律に関わるレファレン スの比率は全体の件数からみるとそれほど多いほうでは ない。その内容の多くは授業で出された課題資料の所蔵 の検索や判例の検索や法令検索方法が中心である。しか し稀に外国法の検索, 外国の判例検索, 旧法令の検索な ど，回答までに時間のかかる事例に遭遇することあある。 本稿では法律関係の文献の検索方法を, 現行法令, 旧 法令, 新しい法令, 条例, 判例, といった項目ごとに早 稲田大学中央図書館レファレンスカウンターでの事例と 合わせて，オンラインデータベースを使った国内法の検 索を中心に紹介していきたい。

\section{II. 法令の検索}

法令とは憲法を頂点として，その下に制定される法律， 政令, 栜令, 府令, 省令, 規則, ならびに地方公共団体 の制定する条例, 規則のことをいう。法令の検索にあたっ ては，まず利用者がさがしたい法令が国内法なのか外国 法なのか，国内法のなかでも国が制定した法か地方公共 団体が制定した条例か, 外国法の場合には国際法である のかのかどうか聞きとる必要がある。漠然とした最初の

'Mituyasu HATTORI：=169-8050 東京都新宿区西早稲田 1-6-1 Tel.03-5286-1659 Fax.03-3207-9224 mituyasu@waseda.jp

(2003 年 2 月 17 日 受理)
受付け時点で求めることを十分聞きとることがレファレ ンスのスタートである。

そのうえで現在む有効な現行法令なのか, 廃止されて しまった法令であるのか, 公布されて間むない新しい法 令であるのかを調べる必要がある。それによって検索方 法もそれぞれ異なってくるからである。憲法や民法, 刑 法のような法律であれば誰であ一度くらいは名前を聞い たことがあり，いわゆる六法全書をみれば，それらの法 令が収録されていることは容易に想像できるだろう。し かしいわゆる六法全書は正確な法令名がわからないと, なかなか求めるものが見つけられないものである。

例えば最近, 駅構内のエレベーター, エスカレーター の設置工事が頻繁に行われているが，いわゆる「バリア フリー」推進の根拠となっている法令は何かということ で, 検索してみようとしても, その正確な法令名と実際 に新聞などで使われている通称（バリアフリー法）の法 令名が一致しないためにさがしている法令がすぐにみつ

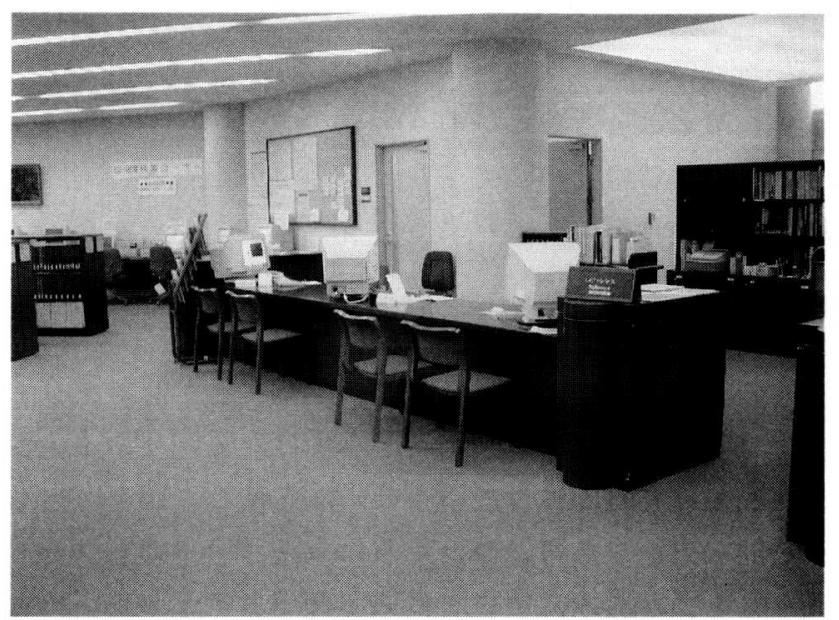

医学図書館 $2003 ； 50(1) ： 41-45$. 


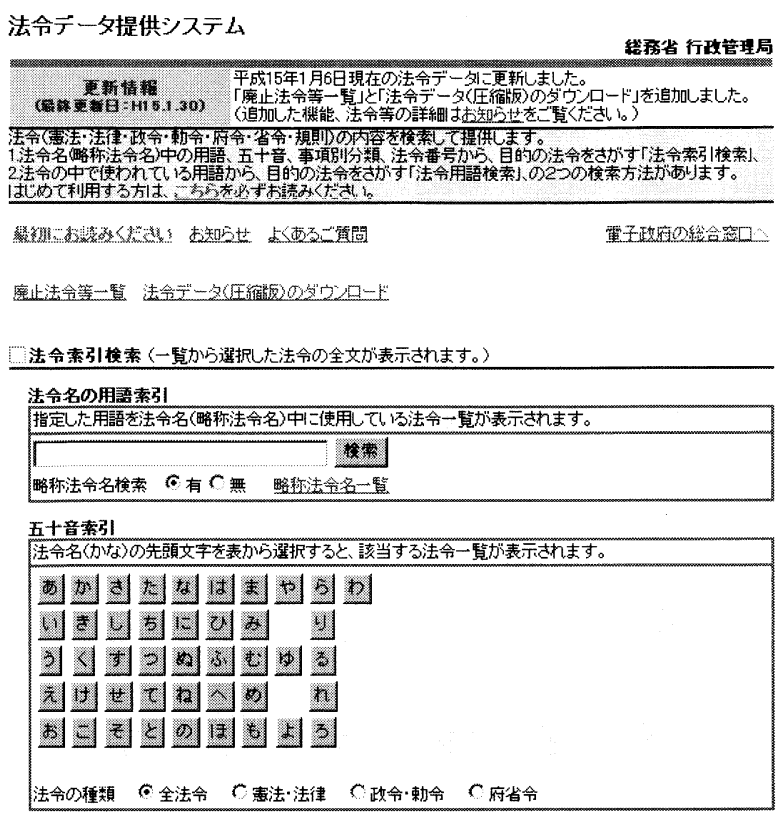

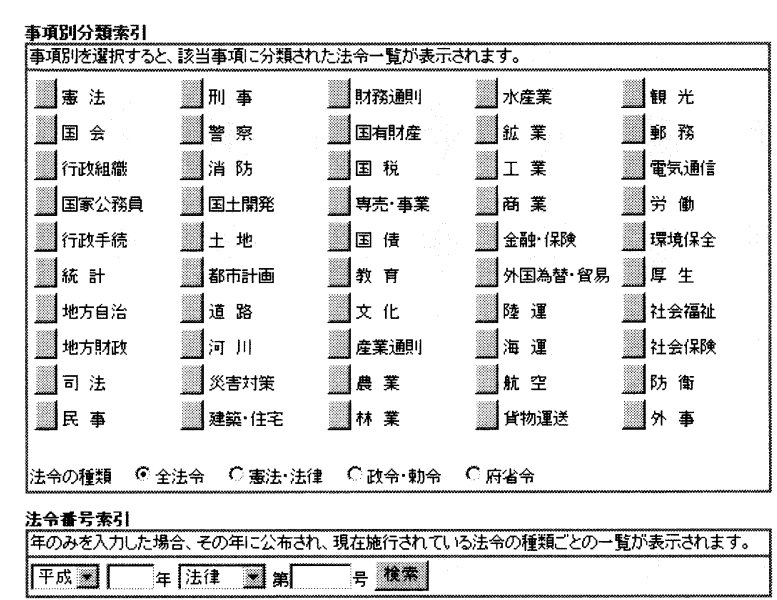

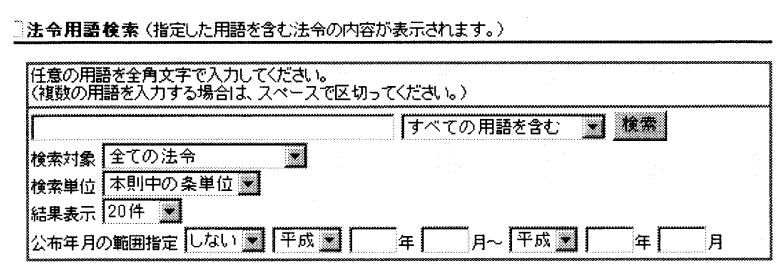

図 1. 法令データ提供システム

けられないということがある。

それではこの「バリアフリー」の事例をもとに実際に 現行法の検索を行ってみよう。

\section{1. 現行法の検索}

先に挙げた「バリアフリー」の事例は私がレファレン スカウンターで実際に利用者から受けた質問である。現 行法を検索する際には最新版の六法を使うのがもっとも 一般的な方法である。ひとくちに六法といってもコンパ クトなむのから大六法まで多種多様であるが, 小さい六
法は法令の収録数が少なくさがしている法令が収録され ていないということもある。そこで， 2 分冊から成り比 較的大きい部類に属する岩波書店の『六法全書』を引い てみた。しかしバリアフリー法という名称ではさがして いる法令をみつけることができなかった。そこで新聞記 事，事典などを使って調査することから始める。例えば 『現代用語の基礎知識』（2003 年版）で「バリアフリー 法」をみると，「高齢者，身体障害者等の公共交通機関 を利用した移動の円滑化の促進に関する法律」という正 式名称之説明がみつかる。冒頭で述べたように法令や判 例など法律関係の事柄を検索する際に困難を伴う点のひ とつに，世間一般で言われる通称名と正式な法令名，判 例集における事件名をどのように結びつけるかというこ とが挙げられる。

最近ではインターネットによる法律検索が一般的にな り，総務省行政管理局が官報を基にデータを整備した 「法令デー夕提供システム」（憲法・法律・政令・勅令・ 府令・省令・規則の全文が検索可能), (URL : http:// law.e-gov.go.jp/cgi-bin/idxsearch.cgi)（図 1) という 非常に便利なサイトがある。私も最近はむっぱら六法よ りあこのサイトで法令を検索することが多くなっている。

このサイトの便利な機能として, トップページに「略 称法令名一覧」という項目があり，「バリアフリー法」 で検索すると通称名の一覧が表示され，「交通バリアフ リー法一高齢者, 身体障害者等の公共交通機関を利用し た移動の円滑化の促進に関する法律」というょうに六法 全書の法令名索引と同様の結果が得られる。この「法令 データ提供システム」の「略称法令名一覧」をカウンター に法令を検索に来た利用者にもたびたび紹介している。

「法令デー夕提供システム」のその他の便利な機能と して「法令用語検索」がある。入力欄にキーワードを入 力すると，そのキーワードを条文中に含む法令の一覧が 表示され，さらにその詳細もみることができる。

さらに 2003 年 1 月からは,「法令デー夕提供システム」 が開設された 2001 年 4 月以降に廃止された法令，およ び失効等法令の一覧, 全文がみられるようになった。

このように法令, とりわけ現行法については現在，才 ンラインデータベースの整備により, 多くの情報が自宅 や研究室にいながらにして無料で入手できるようになっ た。以前ならば法令を調べるに際して, 多少なりとも法 律学の知識が必要だったものが, オンライン検索機能の 発達によって他データベースと同様, 誰にであ容易に検 索できるようになってきている。 


\section{2. 旧法令}

すでに廃止された法令や改正されて効力がなくなって しまった条文を調べるには，六法全書に収録されている ような主要な法律であれば，廃止，改正以前の年代の六 法全書をみれば，さがすことができる。六法に掲載され ていないような法令を調べる場合には，当時の法令全書 や官報をみれば，同様にさがしている法令，条文をさが すことができる。また加除式の『現行法規総覧』や『現 行日本法規』にも主要な旧法令を収録した巻がある。

廃止された法令が，いつ廃止されたのか判らないとき には，上記のような加除式の法令集の場合，旧法令の改 廃についての索引がついている。治安維持法という法律 が廃止されたのは知っているがその法律がいつ廃止され たのか判らない場合，『現行法規総覧』を例に用いて調 べると索引の巻に「旧法令改廃沿革索引」という巻があ る。50 音順に法令名がならんでおり，「ち」をさがすと， 治安維持法は大正一四年四月二十二日に公布され，昭和 二○年一○月一日に廃止されたとある。

また第二次世界大戦前の屯のを中心として, 失効した 法令のなかで重要な法令を集めたものとして, 我妻栄編 『旧法令集』（有斐閣 1968 年）がある。

このように旧法令については, 印刷媒体を使った検索 が中心であり，法学部を有する大学の図書館や国立国会 図書館, 各都道府県の中央図書館規模の図書館でないと 資料が揃っていないため検索できないこともあるだろう。 ただし先に紹介したように「法令デー夕提供システム」 であ平成 13 年 4 月 1 日以降に廃止，失効等になった法 令については検索が可能となっている。

\section{3. 新しい法令}

最新の法令を検索する際に，もっとも一般的な方法は 官報をみることである。過去一週間分の官報については 財務省印刷局がインターネット上に PDF 形式で全文を 公開している。(URL: http://kanpou.pb-mof.go.jp) デー夕は毎日更新され，その日の正午には当日の官報が 閲覧できるようになっている。ただし官報や法令全書の 場合, 新しくできた法令については全文が掲載されるが, 改正の場合は「OX 法の一部を次のように改正する。第 1条の『XXX』を『YYY』と改める」というょうに変 更があった部分のみが掲載されるようになっている。

前述の「法令デー夕提供システム」で屯新しい法令を 検索することができる。同サイトは月に一度データが更 新されて抢り，「打知らせ」のページに「新規法令」と 「未施行法令」の一覧が掲載され，ここでは全文がみら
れるようになっている。次回の更新予定日が掲載されて おり, 最新の法令を検索する際にも参考之なる。

印刷媒体では財務省印刷局が月 2 回発行している『時 の法令』が新法令に解説を加えて速報している。また法 律雑誌に屯法令の制定, 改廃について速報, 解説を掲載 するコーナーが設けられている。例えば『ジュリスト』 では「新法令」,「廃止法令」,『法律時報』では「新法令 解説」である。

\section{4. 条例}

地方自治体の条例はこれまで紹介してきたような一般 の法令集には収録されていない。主要な条例を収録した あのとして『地方自治条例集』（ぎょうせい 加除式）が ある。ただしここに揭載されていないような条例を調 べたり,さらに厳密に調べたりする場合は当該地方公共 団体の公立図書館に問い合わせをするか県庁や市役所, 役場等に問い合わせが必要になることあある。

インターネット上で条例を調べる場合には，鹿児島大 学法文学部法政策学科が運営する「全国条例データベース」 (URL: http://joreimaster.leh.kagoshima-u.ac.jp/) というサイトがある。

先日,「昨年暮れ, 千代田区で導入され，テレビや新 聞などでもたびたび紹介された歩きたばこ禁止条例の中 身をみてみたい」という質問をレファレンスカウンター で受けた。そこで早速このデータベースを開き，「地域 別」から「東京都 23 区・千代田区」をクリックした。 すると「千代田区例規集」の画面が表示された。新聞記 事などを検索したところ，この条例については「路上禁 煙条例」といった通称名で紹介されている。そこで「千 代田区例規集」のキーワード検索の画面で「路上」，「禁 煙」の二つのキーワードをかけあわせて検索を実行して みた。すると「安全で快適な千代田区の生活環境の整備 に関する条例」という条例の第 21 条に「路上禁煙地区」 が規定され，第 21 条をクリックするとその内容を確認 することができた。

地方公共団体の条例については，それぞれの自治体に よってインターネット上に公開している条例の数に差が あるため, このサイトからの検索ですべての条例の全文 を入手できるわけではないが, 最近では多くの自治体が インターネット上に条例を公開するようになってきてい るので条例に関わる質問があった場合には，まずこのサ イトを検索してみるとよいだろう。 


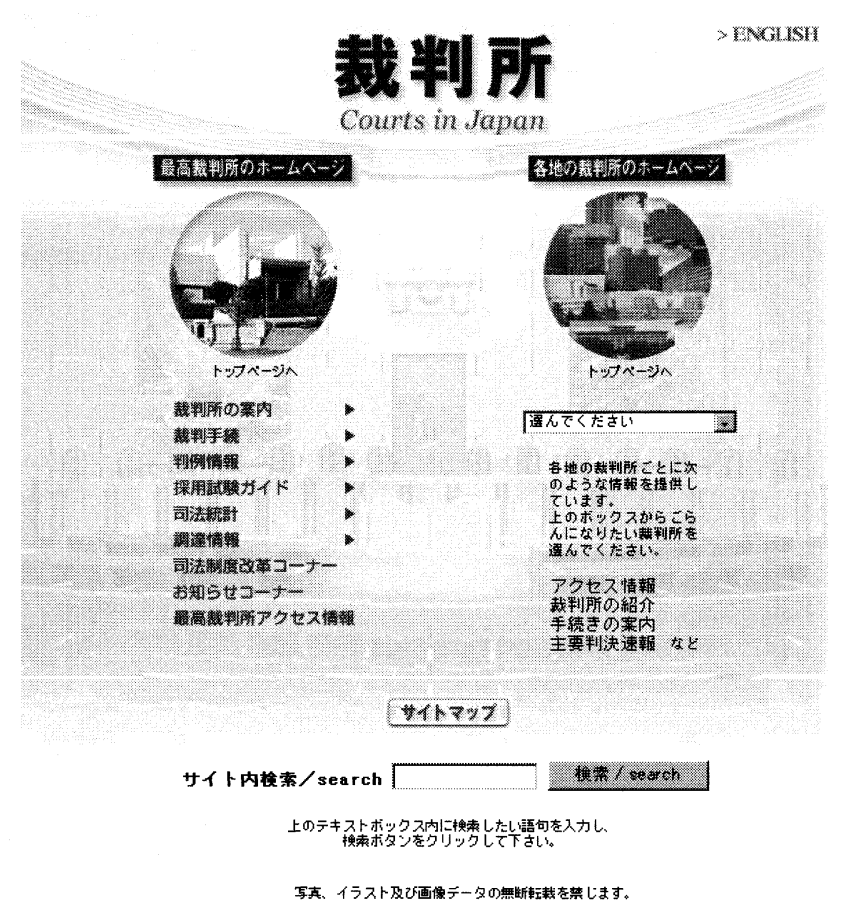

図 2. 裁判所ホームページ

\section{III. 判例の検索}

判例を検索する際にまず注意しなければならないこと は，裁判所で下された判決が全て判例集に掲載されるわ けではないということである。司法統計によれば最高裁 判所が平成 13 年度の 1 年間に処理した事件は民事, 刑 事訴訟事件だけでも 6,000 件を超えているが，このうち 公式な判例集である, 『最高裁判所民事判例集』, 『最高 裁判所刑事判例集』に掲載される判例は 100 件にも満た ない。判例検索をするにあたってはまず，このことを念 頭におく必要がある。現在では最高裁判所のホームペー ジや「LEX/DB」などのインターネットを利用しての 検索, また『判例時報』をはじめとして冊子体の判例掲 載誌によっても, 最高裁判所や下級裁判所の判例を検索 することができる。

判例に関するレファレンスをカウンターで受けた場合, 早稲田大学中央図書館では,「LEX/DB」（明治 8 年か ら今日にいたるまでの主要判例の全文と関連情報を収録 した TKCによる有料データベース)を契約しているた め,まず「LEX/DB」を検索する。利用者のほうであ らかじめ判決年月日, 判決の下された裁判所がわかって いれば「LEX/DB」の検索画面で判決年月日, 裁判所 を指定して検索すると指定項目に誤りがなければ，この 2 項目の限定で結果の一覧表示をひとつひとつ確認して
いけば求める判決をみつけられるはずである。ただし， 実際に利用者が判決年月日や判決の下された裁判所を指 定してくることは稀であり，多くの場合は「宇奈月事件 の判決は何に掲載されているか」,「ハンセン病訴訟の判 決で 1 年ほど前に原告が勝訴した地裁の判決を全文読み たい」といった聞き方をしてくる。この 2 つの事例は実 際にカウンターで聞かれた事例であるが, 後者の事例か ら実際に判決を調べてみたい。

まず，判決年月日を特定するにあたって新聞記事索引 データベース等を利用して, 記事内容から判決年月日を 特定する。早稲田大学図書館では朝日新聞のデータベー ス「DNA」を契約しているが，無料で提供されている 新聞社のサイトを利用することもできる。1 年ほど前の 判決と記事ということで過去 2 年間の記事の全文検索が 無料で行える毎日新聞のサイト (URL: http://www. mainichi.co.jp/）を利用する。記事検索欄に「ハンセ ン病訴訟 原告勝訴 地裁判决」と入力し検索する。す ると 3 件ヒットする。結果の一覧をみると 3 件目に「八 ンセン病訴訟 熊本地裁判決 2001.5.25」という記事の 要旨がある。これをクリックすると「熊本地裁で 11 日 言い渡されたハンセン病国家賠償訴訟の判決」とある。 この判决年月日, 判決裁判所名をむとに「LEX/DB」 の検索を行う。「LEX/DB」の検索画面で判決日を“平 成 13 年 5 月 11 日”と入力し, 裁判所名は一覧から熊本 地方裁判所を選択し検索を実行する。すると検索結果は 1 件と表示され「全文」をクリックすると判決の全文が 表示される。「LEX/DB」は有料データベースであり, 契約をしていないと利用できないデータベースであるが， 優れている点として明治期から昭和戦前期の主要な判例 を網羅している点, さらに「著名事件名」, すなわち通 称の事件名から判例を検索できる点，加えて当該判決に 関わる関連情報として判例解説掲載誌の書誌が表示され ている点，および審級情報がひとめでわかるといった点 が挙げられよう。

$\lceil\mathrm{LEX} / \mathrm{DB} 」$ 以外に判例を検索できるサイトとして 最高裁判所のホームページ (URL: http://www. courts.go.jp/）（図 2 ）がある。同サイトには「最高裁 判所民事判例集，刑事判例集」に掲載された判例の全文 が閲覧できるようになっている。さらに 1969 年以降の 主要な知的財産関係の判例を集めた「知的財産権裁判例 集」, 同じく 1969 年以降の主要な労働事件の判例を集め た「労働事件裁判例集」が検索できる。そのほかに 2002 年 3 月以降の下級裁判所の主要な判例を検索でき るようになっている。検索項目に著名事件名がないため 
に, 先述のように新聞記事索引データベースや事典等で 判決年月日を限定して調べたほうが使いやすいだろう。

判決の全文でなく要旨だけを知りたい，判例の解説を みたいという場合であれば，国立国会図書館の雑誌記事 索引を使って検索すれば判例解説をさがすことができる。 判例の検索についてはオンライン検索をする場合「L $\mathrm{EX} / \mathrm{DB} 」$ がすっも使い勝手がいい。ただし有料のサ イトであり，法学部を持たない大学でこのデータベース を購入することは難しいだろう。最高裁判所の主要な判 決であれば先ほど紹介した最高裁判所のホームページか ら検索することができる。下級裁判所の判決となると同 最高裁ホームページの下裁主要判決情報があるのみであ る。他の方法としては，判決年月日や裁判所名を指定し て冊子体の判例集を所蔵している大学に ILLで依頼す る必要がある。

\section{IV. おわりに}

先述のとおり以前ならば法令を調べるに際して, 多少 なりと屯法律学の知識が必要だったものが，オンライン
検索手段の発達によって他データベースと同様, 誰にで あ容易に検索できるようになりつつある。法律に関わる データベースに限らず全てのオンライン上の情報を利用 する際に注意すべきことであるが，インターネット上の 情報は八ッカーなどによって簡単に書き換え等が可能で ある。以前, 省庁のホームページが書きかえられるとい う被害を受けたことがあったが，各人の利害関係が大き く関係する法令データベースや判例データベースが何者 かによって意図的に書きかえられないとあ限らない。学 術論文に法令, 判例等を引用する場合は念のために冊子 体の法令集や判例集で確認をする必要があるだろう。

しかし，オンラインデータベースの普及によって法情 報にアクセスしやすくなったことは事実である。今回紹 介したサイトにアクセスして，関心，興味のある判例， 法令を検索してみていただきたい。

\section{参考文献}

- 西野喜一『法律文献学入門』(有斐閣，2002 年)

・法律図書館連絡会ユーザーズマニュアル作成委員会編『法律困 書館ユーザーズマニュアル（全訂版）』（法律図書館連絡会, 2001 年) 